neering Journal, 276, 283-288. doi: 10.1016/j.cej. 2015.04.039

9. Nguyen, H. T. T., Nevoigt, E. (2009). Engineering of Saccharomyces cerevisiae for the production of dihydroxyacetone (DHA) from sugars: A proof of concept. Metabolic Engineering, 11 (6), 335-346. doi: 10.1016/j.ymben.2009.07.005
10. Demkiv, O. M., Paryzhak, S. Y., Gayda, G. Z., Sibirny, V. A., Gonchar, M. V. (2007). Formaldehyde dehydrogenase from the recombinant yeast Hansenula polymorpha: isolation and bioanalytic application. FEMS Yeast Research, 7 (7), 1153-1159. doi: 10.1111/j.1567-1364.2007. 00255.x

Дата надходження рукопису 22.07.2015

Синенька Марія Миколаївна, інженер, Відділ аналітичної біотехнології, Інститут біології клітини НАН України, вул. Драгоманова, 14/16, м. Львів, Україна, 79005

E-mail: maria-swntozelska@ukr.net

Гайда Галина Зуфарівна, кандидат хімічних наук, старший науковий співробітник, Відділ аналітичної біотехнології, старший науковий співробітник, Інститут біології клітини НАН України, вул. Драгоманова, 14/16, м. Львів, Україна, 79005

E-mail: galina.gayda@gmail.com

Клепач Галина Миколаївна, кандидат біологічних наук, доцент, Дрогобицький державний педагогічний університет, вул. Т. Шевченка, 23, м. Дрогобич, Львівська обл., Україна, 82100

E-mail:pavlishko@yahoo.com

Іваш Марія Федорівна, Відділ Аналітичної біотехнології, інженер, Інститут біології клітини НАН України, вул. Драгоманова 14/16, м. Львів, Україна, 79005

Гончар Михайло Васильович, доктор біологічних наук, професор, завідувач відділу Аналітичної біотехнології, Інститут біології клітини НАН України, вул. Драгоманова, 14/16, м. Львів, Україна, 79005 E-mail: mykhailo1952@gmail.com

УДК 631.5: 581.4: 58.08

DOI: $10.15587 / 2313-8416.2015 .47982$

\title{
ANALYSIS OF THE LIVING STATE OF CENOPOPULATION OF POLYCENTRIC BIOMORPH POA ANGUSTIFOLIA L.
}

\section{O. Kuznetsova}

For studying the living state of cenopopulation of polycentric biomorph it was offered to use the method of correlative analysis and asymmetry of vegetative signs of Poa angustifolia $L$. The received data demonstrated that the most informative indicators are the generalized correlation coefficient and unsymmetrical factor. The use of received criteria allows define the living state of vegetatively movable specie at only the single research

Keywords: living state, cenopopulations of polycentric biomorphs, vegetative signs of Poa angustifolia $L$.

Для вивчення життєвого стану иенопопуляції поліцентричної біоморфи було запропоновано використання методу кореляційного аналізу і асиметрї вегетативних ознак Poa angustifolia L. Oтримані дані показали, щзо найбільш інформативними показниками є узагальнений коефіцієнт кореляції $і$ коефіцієнт асиметрії. Використання отриманих критерїв дозволить визначати життєвий стан вегетативно рухомого виду вже при одноразовому дослідженні

Ключевые слова: життєвий стан, ценопопулячї̈ полічеентричності біоморф, вегетативні ознаки Роа angustifolia $L$.

\section{Introduction}

The revelation of indicative signs and methods that allow define the vitality of vegetable population and make the prognosis of its development and so of the whole phytocenosis was always an important task of ecology.

Morphologic structure of the plant is a united system of interconnected organs and its elements. The study of internal connections between the separate organs is important for solving many theoretical and practical problems of ecology and phytocenology [1]. Internal connections in biological objects can define the degree of its correspondence to the concrete ecotope and the living state of organisms [2]. The prevalence of the high posi- tive connections among the functionally important signs demonstrates the certain coordination in morphogenesis, in functioning and development of individuals, the fitness to ecotope conditions; its lack can indicate the disintegrative processes and be an early diagnostic signal of destructive phenomena [3].

\section{Analysis of literature data and the statement} of the problem

Among the methods of defenition of the living state of cenopopulations the scientists of the previous century often used an analysis of aged groups [4-7]. The modern scientists pay attention to the same method [8- 
12]. The use of this method at studying the species of polycentric biomorph is impossible because of intensive vegetative reproduction of these plants by the plagiotropic system of sprouts. At the same time the one individual divides in several clones - independent organisms at the certain distance from each other. In thick grass such plants can sprout in ecotope of other individuals forming an extremely complicated interlacement. In these circumstances it is very difficult to separate the concrete organisms in vegetable group in most cases it is impossible especially in number that is necessary for reliable statistical analysis.

That is why at studying vegetatively movable plants the main elementary and count unit is partial bush or sprout but not an individual [13-15]. The study of sprouts in such cenopopulations was often used especially for study of dynamics of grass density and its reaction on agrotechnical arrangements. It was not used for an analysis of the living state. At least such information is absent in literature that we used. There are many important signs that characterize vegetative sprout of cereals: the height of sprout, its length, the width of laminas and other but there was not observed the one the most influential sign.

\section{Aim and problems of research}

Considering the aforesaid the revelation of diagnostic and prognostic indicators of the living state of plagiotropic plants on example of vegetative sprouts of the bunch cereal Poa angustifolia L. became the aim of research.

For attending the set aim there were solved the problems of the search of the most informative sings of vegetative sprout and methods of definition of vitality stage of vegetatively movable cenopopulation at the single receipt of values.

\section{Materials and methods of research}

The next signs were taken for the research: height of sprout, length and width of each leaf, its number. On these parameters there were count the reserve of leaves length, the mean leaf width and an area of leaf surface.

Vegetative sprouts of the cereal Poa angustifolia L. were removed from the four ecotopes with different conditions: 1) from the plot of steppe virgin land situated in plakor conditions on the top of the right bank of dividing plateau of the river Samara in Dnepropetrovsk region (variant "steppe"); 2) from horizontal plot in parietal conditions of the right bank of mentioned river (variant "meadow parietal grass"); 3) from the lawn of the central part of the botanical garden of Dnepropetrovsk national university (variant "lawn"); 4) among the cereal-forbs grass in south-western part of the same botanical garden near to the work plot (variant "meadow grass of botanical garden").

On each test area were taken 100 vegetative sprouts of cereal Poa angustifolia L. on the random basis in first two days of July during three years. All studied signs were sequentially compared with each other on the method of correlative analysis [16] and its dynamics was studied. Characteristics of cenopopulation vitality were evaluated on the mean weighted correlation coefficient and unsymmetrical factor.

\section{The results of researches}

In the first year of research vegetative sprouts had almost similar initial mean weighty correlation coefficients: in variant "steppe"- Rmean $=0,51$, in variant "meadow parietal grass" - Rmean $=0,53$, in variant "meadow grass of botanical garden" - Rmean=0,52, in variant "lawn" - Rmean $=0,41$. In the last variant the moving of grass brought principal corrections in detected regularity that is why an initial coefficient is differ (Table 1).

Table 1

The mean correlation coefficient (R) of signs of vegetative sprouts of Poa angustifolia L. in different ecotopes

\begin{tabular}{|c|c|c|c|c|}
\hline \multirow[b]{2}{*}{ Sign } & \multicolumn{4}{|c|}{ Ecotopes } \\
\hline & «steppe» & $\begin{array}{c}\text { «meadow parietal } \\
\text { grass» }\end{array}$ & $\begin{array}{l}\text { «meadow grass of } \\
\text { botanical garden» }\end{array}$ & «lawn» \\
\hline \multicolumn{5}{|c|}{$\mathbf{1}^{\text {st }}$ year of research. Mean correlation coefficient $(\mathrm{R})$} \\
\hline Sprout height & 0,58 & 0,61 & 0,60 & 0,43 \\
\hline Leaves length reserve & 0,66 & 0,66 & 0,64 & 0,53 \\
\hline Length of the leaf 2 & 0,54 & 0,58 & 0,55 & 0,45 \\
\hline Leaves number & 0,31 & 0,27 & 0,26 & 0,27 \\
\hline Mean leaf width & 0,26 & 0,35 & 0,40 & 0,22 \\
\hline Leaf surface area & 0,71 & 0,70 & 0,68 & 0,57 \\
\hline Mean coefficient of all signs (Rmean) & 0,51 & 0,53 & 0,52 & 0,41 \\
\hline \multicolumn{5}{|c|}{2 year of research. Mean correlation coefficient $(\mathrm{R})$} \\
\hline Sprout height & 0,60 & 0,59 & 0,53 & 0,47 \\
\hline leaves length reserve & 0,69 & 0,65 & 0,61 & 0,58 \\
\hline Length of the leaf 2 & 0,53 & 0,45 & 0,52 & 0,39 \\
\hline Leaf number & 0,33 & 0,34 & 0,26 & 0,29 \\
\hline Mean leaf width & 0,29 & 0,32 & 0,28 & 0,26 \\
\hline Leaf surface area & 0,70 & 0,68 & 0,56 & 0,58 \\
\hline Mean coefficient of all signs (Rmean) & 0,52 & 0,50 & 0,46 & 0,43 \\
\hline \multicolumn{5}{|c|}{ 3 year of research. Mean correlation coefficient $(\mathrm{R})$} \\
\hline Sprout height & 0,61 & 0,55 & 0,45 & 0,50 \\
\hline Leaves length reserve & 0,68 & 0,60 & 0,57 & 0,60 \\
\hline Length of the leaf 2 & 0,50 & 0,47 & 0,46 & 0,37 \\
\hline Leaf number & 0,33 & 0,23 & 0,21 & 0,36 \\
\hline Mean leaf width & 0,31 & 0,24 & 0,29 & 0,25 \\
\hline Leaf surface area & 0,69 & 0,67 & 0,55 & 0,60 \\
\hline Mean coefficient of all signs (Rmean) & 0,52 & 0,46 & 0,42 & 0,45 \\
\hline
\end{tabular}


In the sequel the changes caused by the range of certain factors that defined the state of studied cenopopulation were retraced in correlated pleiads of every ecotope. These processes were caused by the next phytodynamic phenomena that are specific for every variant of discussed experiment.

1. Variant "steppe". On this plot the population of angustifolia L. is on the stage of ripeness with stable definitive development. In the years of research this specie functioned as a co-dominant of phytocenosis with typical representatives of steppe. Its participation in grass composition was not changed during the years of research.

2. Variant "meadow parietal grass". The population of Poa angustifolia L. is at the beginning of regress now. During the years of research this specie passed from the state of dominant to the status of co-dominant together with quick grass (Elytrigia repens (L.) Nevski).
3. Variant "meadow grass of botanical garden". The population of Poa angustifolia L. is at the high point of regress. Within 3 years this specie passed from the position of dominant to the category of secondary specie. The quick grass (Elytrigia repens (L.) Nevski) occupied a predominant position.

4. Variant "lawn". The regular mowing creates the favorable conditions for progressive development of Poa angustifolia L. This specie appeared here independently and gradually passed from the secondary position to the role of co-dominant of phytocenosis and consequently the population is at the middle of the stage of invasion (formation).

Just these differences caused the corresponding dynamics of morphometric signs of sprouts and changes of its interconnections. The calculations demonstrated that in the variant "steppe" the mean weighty correlation coefficient of vegetative signs (Rmean) changed less than other variants during 3 years - by 0,01 unit (Table 2 ).

Table 2

Changes of the mean correlation coefficients (R) among the signs of vegetative sprout of Poa angustifolia L. during 3 years

\begin{tabular}{|l|c|c|c|c|c|c|c|}
\hline \multirow{2}{*}{ Ecotope } & \multicolumn{6}{|c|}{ Mean correlation coefficients (R) of vegetative signs } & $\begin{array}{c}\text { Changes of inte- } \\
\text { gral indicator of } \\
\text { correlated pleiad, } \\
\text { Rmean }\end{array}$ \\
\cline { 2 - 8 } & $\begin{array}{c}\text { Leaf } \\
\text { surface } \\
\text { area }\end{array}$ & $\begin{array}{c}\text { Sprout } \\
\text { height }\end{array}$ & $\begin{array}{c}\text { Leaf length } \\
\text { reserve } \\
\text { (amount) }\end{array}$ & $\begin{array}{c}\text { Length of } \\
\text { the leaf } 2\end{array}$ & $\begin{array}{c}\text { Leaf } \\
\text { number in } \\
\text { sprout }\end{array}$ & $\begin{array}{c}\text { Leaf } \\
\text { width }\end{array}$ & $+0,0,04$ \\
\hline «Lawn, Invasion stage & 0,03 & $+0,07$ & $+0,07$ & $-0,08$ & $+0,09$ & $+0,03$ & $+0,04$ \\
\hline $\begin{array}{l}\text { «Steppe», normal pop- } \\
\text { ulation }\end{array}$ & $-0,02$ & $+0,03$ & $+0,02$ & $-0,04$ & $+0,02$ & $+0,05$ & $+0,01$ \\
\hline $\begin{array}{l}\text { «Meadow parietal } \\
\text { grass», the beginning } \\
\text { of regress }\end{array}$ & $-0,03$ & $-0,06$ & $-0,06$ & $-0,11$ & $-0,04$ & $-0,11$ & $-0,07$ \\
\hline $\begin{array}{l}\text { «Meadow grass of bo- } \\
\text { tanical garden», } \\
\text { The high point of re- } \\
\text { gress }\end{array}$ & $-0,13$ & $-0,15$ & $-0,07$ & $-0,09$ & $-0,05$ & $-0,11$ & $-0,10$ \\
\hline
\end{tabular}

An invariability of integral indicator of correlated pleiades (Rmean) became the one of more typical determinative signs of population vitality. Its stability demonstrated that the population is in conditions of ecologic correspondence and has a "normal" status.

The mowing of the "lawn" favored the reverse integrative phenomena. The narrow-leaved bluegrass gradually approached to genetically caused morphological proportionality relative to the vegetative sprout as an elementary structural unit of population. The mean coefficients of population did not reduce but increased here within $0,03-0,09$ for 3 years. The connections of the second upper leaf were an exception. It can be explained by its high position in the grass and consequently the greatest portion of cut part at "cutting off" the lawn.

In variants "meadow parietal grass" and "meadow grass of botanical garden" the loose layer of live and died leaves and stems mass was accumulated on the soil surface, it hold the moister so favored the development of moisture-loving co-dominant of quick grass and inhibition of the dominant narrow-leaved bluegrass. Probably that is why the processes of disintegration of cenopopulation of bluegrass started. On the "meadow parietal grass" the general decrease of integral indicator of correlated pleiad R mean is 0,07 units, on "meadow grass of botanical garden" - 0,10 units (table 2).

The study of changes in correlated pleiad in system of vegetative sprout demonstrated the clear quantitative markers in conditions of the state of population of Poa angustifolia L. in its development. The more informative one is the mean correlation coefficient Rmean on all indicators for every variant (table1). Its stability testifies that the studied population is at the stage of the "normal" development. At "invasive" stage this indicator increases, in "regressive" one - decreases.

The mentioned structural changes of vitality of studied cenopopulations were proved by an analysis of the symmetry of the same vegetative signs. The dynamics of unsymmetrical factor demonstrated that the "normal" population - "steppe" was characterized by the stable $\mathrm{As}_{\text {mean }}$ that changed during three years respectively: 0,$34 ; 0,33 ; 0,33$. An "invasive" population - "lawn" was determined by the gradual decrease of $\mathrm{As}_{\text {mean }}: 0,45 ; 0,41$; 0,38 , "regressive" population - variants "meadow parietal grass" and "meadow grass of botanical garden" - by the gradual increase of $\mathrm{As}_{\text {mean }}$ respectively on variants and years: 0,$55 ; 0,59 ; 0,62$ и 0,$53 ; 0,62 ; 0,75$ (Table 3 ). 
The dynamics of unsymmetrical factors (As) among vegetative signs of the sprouts of Poa angustifolia L. of the different populations

\begin{tabular}{|c|c|c|c|c|}
\hline \multirow[b]{2}{*}{ Indicator } & \multicolumn{4}{|c|}{ Ecotope } \\
\hline & «steppe» & $\begin{array}{l}\text { «meadow parietal } \\
\text { grass } ~\end{array}$ & $\begin{array}{l}\text { «meadow grass of botani- } \\
\text { cal garden» }\end{array}$ & «lawn» \\
\hline \multicolumn{5}{|c|}{1 year of research. Unsymmetrical factor $(\mathrm{As})$} \\
\hline Sprout height & 0,15 & 0,54 & 0,51 & 0,25 \\
\hline Leaf length reserve & 0,62 & 0,84 & 0,35 & 0,43 \\
\hline Length of the leaf 2 & 0,20 & 0,51 & 0,96 & 0,46 \\
\hline Leaf number & 0,06 & 0,34 & 0,53 & 0,45 \\
\hline Mean leaf width & 0,51 & 0,16 & 0,11 & 0,28 \\
\hline Leaf surface area & 0,63 & 0,92 & 0,74 & 0,81 \\
\hline Mean coefficient of all signs $\left(\mathrm{As}_{\text {mean. }}\right)$ & 0,34 & 0,55 & 0,53 & 0,45 \\
\hline \multicolumn{5}{|c|}{2 year of research. Unsymmetrical factor (As) } \\
\hline Sprout height & 0,17 & 0,34 & 0,23 & 0,28 \\
\hline Leaf length reserve & 0,59 & 0,41 & 1,02 & 0,37 \\
\hline Length of the leaf 2 & 0,15 & 1,32 & 0,70 & 0,48 \\
\hline Leaf number & 0,05 & 0,04 & 0,73 & 0,36 \\
\hline Mean leaf width & 0,64 & 0,43 & 0,16 & 0,25 \\
\hline Leaf surface area & 0,37 & 0,98 & 0,85 & 0,74 \\
\hline Mean coefficient of all signs $\left(\mathrm{As}_{\text {mean }}\right)$ & 0,33 & 0,59 & 0,62 & 0,41 \\
\hline \multicolumn{5}{|c|}{3 year of research. Unsymmetrical factor (As) } \\
\hline Sprout height & 0,14 & 0,49 & 0,68 & 0,25 \\
\hline Leaf length reserve & 0,51 & 0,78 & 1,03 & 0,26 \\
\hline Length of the leaf 2 & 0,22 & 0,62 & 0,99 & 0,53 \\
\hline Leaf number & 0,11 & 0,21 & 0,61 & 0,32 \\
\hline Mean leaf width & 0,58 & 0,65 & 0,40 & 0,14 \\
\hline Leaf surface area & 0,41 & 0,73 & 0,87 & 0,79 \\
\hline Mean coefficient of all signs $\left(\mathrm{As}_{\text {mean }}\right)$ & 0,33 & 0,62 & 0,75 & 0,38 \\
\hline
\end{tabular}

\section{Discussion of the results}

Taking into account the similar initial integral correlation indicators in different variants (Rmean $=0,51-$ $-0,52)$ and its stability for different years on the steppe plot (Table 1) it can be assumed that the critical value of generalized correlation coefficient of the signs of vegetative sprout of perennial cereal of polycentric biomorph is

0,5 . Its decrease (from 0,5 to null; $\mathrm{n} \rightarrow 0$ ) signifies disintegration and regressive state of population, an increase (to coefficient 0,$5 ; \mathrm{n} \rightarrow 0,5$ ) - an invasive stage and formation of specie in the limits of growth.

The received information allows construct the diagnostic table based on correlation coefficient and unsymmetrical factor ratio (Table 4).

Table 4

The criteria of living state (stages of development) of cenopopulation Poa angustifolia L. on morphological signs of vegetative sprouts

\begin{tabular}{|c|c|c|}
\hline State of cenopopulation & $\begin{array}{c}\text { Mean coefficient of correlated pleiad, } \\
\text { Rmean }\end{array}$ & $\begin{array}{c}\text { Mean unsymmetrical factor of quantita- } \\
\text { tive signs of sprout, } \mathrm{As}_{\text {mean }}\end{array}$ \\
\hline Invasive & $<0,50$ & $0,35-0,50$ \\
\hline Normal & $0,50-0,60$ & $<0,35$ \\
\hline Regressive & $<0,50$ & $>0,50$ \\
\hline
\end{tabular}

The lack of such scientific works that use the method of correlated pleiades at studying an age state of vegetable populations at least in literature we know does not give a possibility to compare the received results with other ones. That is why taking into account the initial integral indicators in different variants of research it can be assumed now that the decrease of generalized correlation coefficient of the signs of vegetative sprout of perennial cereal of polycentric biomorph signified the beginning of disintegration. The high amplitude of growth of this indicator demonstrates the regressive state of population and an absence of ecological correspondence to the sprouting conditions. The stage of regressive state of the population corresponds also to an increase of the mean unsymmetrical factor among vegetative signs. On the contrary an increase of the mean correlation coefficient and decrease of unsymmetrical factor testifies an "invasion" of the specie into community. The "normal" state of cenopopulation has the both stable indicators of correlated pleiad and of an asymmetry.

\section{Conclusions}

The use of such criterion allows define the living state of cenopopulation of polycentric biomorph (the stage of its development) already at the single receipt of the values given in the table 1 . This method considerably widens the possibilities of bio-ecological researches at least for herbaceous plagiotropic plants and increases an "efficiency index" of scientific work in the field conditions. It is quite possible that the given criteria can differ from the 
other ones that will be received at studying the other species of plants or the same plants but in the other conditions. But the new assessment of values, its corrections and ecological conclusions are possible only at accumulation of the certain number of relevant information.

\section{References}

1. Lakin, G. F. Biometrija [Text] / G. F. Lakin. - M.: Vyssh. shk., 1990. - 368 p.

2. Ljubarskij, E. L. Opyt prostogo korreljacionnogo analiza vzaimosvjazej $\mathrm{v}$ fitocenoze $\mathrm{s}$ ispol'zovaniem malyh vyborok [Text] / E. L. Ljubarskij // Primenenie kolichestvennyh metodov pri izuchenii struktury fitocenozov. - M.: Nauka, 1972. - P. 53-59.

3. Terent'ev, P. V. Metod korreljacionnyh plejad. Vol. 9 [Text] / P. V. Terent'ev. - Vestn. LGU. - L.: Izd-vo Len. un-ta, 1959. - P. 137-141.

4. Zlobin, Ju. A. Principy i metody izuchenija cenoticheskih populjacij rastenij [Text] / Ju. A. Zlobin. - Kazan': Kazanskij un-t, 1989. - $148 \mathrm{p}$.

5. Uranov, A. A. Zhiznennoe sostojanie vida $v$ rastitel'nom soobshhestve [Text] / A. A. Uranov // Bjull. MOIP. Otd. biol. - 1960. - Vol. 65, Isssue 3. - P. 77-92.

6. Ellenberg, H. Physiologisches und okologisches Verhallen derselbe Pflanzenarten [Text] / H. Ellenberg // Ber. Dtsch. Bot. Ges. - 1953. - B. 65. - H. 10. - P. 350-361.

7. Harper, J. L. The demography of plants [Text] / J. L. Harper, J. White // Annual review of ecology and systematics. - 1974. - Vol. 5, Issue 1. - P. 419- 463.

doi: 10.1146/annurev.es.05.110174.002223

8. Bystrushkin, A. G. K voprosu ob ocenke zhiznennosti cenopopuljacij: sravnenie metodov na primere Rubus Idaeus L [Text] / A. G. Bystrushkin // Vestnik Cheljabinskogo gosudarstvennogo universiteta. - 2007. - Vol. 6. - P. 108-116.

9. Osmanova, G. O. Zhiznennoe sostojanie osobej cenopopuljacij podorozhnika lancentnolistnogo (Rlantago Lanceolata L.) [Text] / G. O. Osmanova // Vestnik Tomskogo gosudarstvennogo universiteta. - 2009. - Vol. 319. - P. 191-194.

10. Ostermeijer, J. Population structure of the rare, long-lived perennial Gentiana pneumonanthe in relation to vegetation and management in the Netherlands [Text] / J. G. B. Oostermeijer, R. V. Veer, J. C. M. D. Nijs // Journal of Applied Ecology. - 1994. - Vol. 31, Issue 3. - P. 428-438. doi: $10.2307 / 2404440$

11. Whigham, D. F. Demographic studies and lifehistory strategies of temperate terrestrial orchids as a basis for conservation [Text] / D. F. Whigham, J. H. Willems. - Orchid conservation. Natural history publications (Borneo), Kota Kinabalu, Sabah, 2003. - P. 137-158.

12. Zavala, M. A. An analytical model of stand dynamics as a function of tree growth, mortality and recruitment: The shade tolerance-stand structure hypothesis revisited [Text] / M. A. Zavala, O. Angulo, R.B. de la Parra, J. C. Lopez-Mareos // Journal of Theoretical Biology. - 2007. - Vol. 244, Issue 3. - P.440-450. doi: 10.1016/j.jtbi.2006.08.024

13. Laptev, A. A. Introdukcija i semenovodstvo gazonnyh trav na Ukraine [Text] / A. A. Laptev, E. A. Kotik, N. K. Kovalenko. - K.: Nauk. dumka, 1978. - 178 p.

14. Sigalov, B. Ja. Dolgoletnie gazony [Text] / B. Ja. Sigalov. - M.: Nauka, 1971. - 311 p.
15. Smirnova, O. V. Ob'em schetnoj edinicy pri izuchenii cenopopuljacij rastenij razlichnyh biomorf [Text] / O. V. Smirnova. - Cenopopuljacii rastenij (osnovnye ponjatija i struktura). - M.: Nauka, 1976. - P. 72-80.

16. Plohinskij, N. A. Biometrija [Text] / N. A. Plohinskij. - M.: Izd.-vo Mos. un.-ta, 1970. - 367 p.

\section{References}

1. Lakin, G. F. (1990). Biometrija. Moscow: Vyssha shkola, 368

2. Ljubarskij, E. L. (1972). Opyt prostogo korreljacionnogo analiza vzaimosvjazej v fitocenoze s ispol'zovaniem malyh vyborok. Primenenie kolichestvennyh metodov pri izuchenii struktury fitocenozov. Moscow: Nauka, 53-59.

3. Terent'ev, P. V. (1959). Metod korreljacionnyh plejad. Vestn. LGU. Leningrad: Izdatelstvo Leinskogo universitetata, 9, 137-141.

4. Zlobin, Ju. A. (1989). Principy i metody izuchenija cenoticheskih populjacij rasteni. Kazan': Kazanskij un-t, 148.

5. Uranov, A. A. (1960). Zhiznennoe sostojanie vida v rastitel'nom soobshhestve. Bjull. MOIP. Otd. biol., 65 (3), 77-92.

6. Ellenberg, H. (1953). Physiologisches und okologisches Verhallen derselbe Pflanzenarten. Ber. Dtsch. Bot. Ges., 65 (10), 350-361.

7. Harper, J. L., White, J. (1974). The Demography of Plants. Annual Review of Ecology and Systematics, 5 (1), 419463. doi: 10.1146/annurev.es.05.110174.002223

8. Bystrushkin, A. G. (2007). K voprosu ob ocenke zhiznennosti cenopopuljacij. Vestnik Cheljabinskogo gosudarstvennogo universiteta, 6, 108-116.

9. Osmanova, G. O. (2009). Zhiznennoe sostojanie osobej cenopopuljacij podorozhnika lancentnolistnogo (Rlantago Lanceolata L.). Vestnik Tomskogo gosudarstvennogo universiteta, 319, 191-194.

10. Oostermeijer, J. G. B., Veer, R. V., Nijs, J. C. M. D. (1994). Population Structure of the Rare, Long-Lived Perennial Gentiana pneumonanthe in Relation to Vegetation and Management in the Netherlands. The Journal of Applied Ecology, 31 (3), 428-438. doi: 10.2307/2404440

11. Whigham D. F., Willems, J. H. (2003). Demographic studies and life-history strategies of temperate terrestrial orchids as a basis for conservation. Orchid conservation. Natural history publications (Borneo), Kota Kinabalu, Sabah, $137-158$

12. Zavala, M. A., Angulo, Ó., Bravo de la Parra, R., López-Marcos, J. C. (2007). An analytical model of stand dynamics as a function of tree growth, mortality and recruitment: The shade tolerance-stand structure hypothesis revisited. Journal of Theoretical Biology, 244 (3), 440-450. doi: 10.1016/j.jtbi.2006.08.024

13. Laptev, A. A., Kotik, E. A., Kovalenko, N. K. (1978). Introdukcija i semenovodstvo gazonnyh trav na Ukraine. Kyiv: Nauk. dumka, 178.

14. Sigalov, B. Ja. (1971). Dolgoletnie gazony. Moscow: Nauka, 311

15. Smirnova, O. V. (1976). Ob'em schetnoj edinicy pri izuchenii cenopopuljacij rastenij razlichnyh biomorf. Cenopopuljacii rastenij (osnovnye ponjatija i struktura). Moscow: Nauka, 72-80.

16. Plohinskij, N. A. (1970). Biometrija. Moscow: Izd.vo Mos. un.-ta, 367.

Рекомендовано до публікачії д-р біол. наук, професор Севериновська О. В. Дата надходження рукопису 25.07.2015

Kuznetsova Olga, applicant, Department of Geobotany, Soil Science and Ecology, Dnipropetrovsk National University, Gagarina ave., 72, Dnepropetrovsk, Ukraine, 49010

E-mail: kuznetsovaolga7@ rambler.ru 